\title{
小麦検出用プライマーセットの開発
}

\author{
内野昌孝 ${ }^{8}$, 増㴊菜美子, 黒澤有希子, 野口智弘*，高野克己 \\ 東京農業大学応用生物科学部 \\ * 東京農業大学食品加工技術センター
}

\section{Specific Primer for Detection of Wheat}

\author{
Masataka Uchino ${ }^{\S}$, Namiko Masubuchi, Yukiko Kurosawa, \\ Tomohiro Noguchi* and Katsumi Takano
}
Department of Applied Biology and Chemistry, Faculty of Applied Bioscience, Tokyo
University of Agriculture, Sakuragaoka 1-1-1, Setagaya-ku, Tokyo 156-8502
* Food Processing Center, Tokyo University of Agriculture,
Sakuragaoka 1-1-1, Setagaya-ku, Tokyo 156-8502

\begin{abstract}
Because wheat contains a protein that can trigger allergies, the presence of wheat must be indicated on food products in Japan. One method for detection of wheat is by PCR. However, in the general detection method, only one primer set is used. In this study, we developed a new primer set for detection of wheat to protect against false results. Two wheat primer sets, 1 and 2, were constructed. The PCR product using set 1 showed a band around the same molecular weight not only as wheat and rye-wheat containing an allergen compound, but also rye. Two amplified DNA sequences specific to wheat and rye-wheat, using primer set 2,800 bp and $500 \mathrm{bp}$, were cloned and the sequences were determined. Two STS primer sets, K800 and K500, were reconstructed based on these sequences. PCR conducted using these sets showed specific bands, $800 \mathrm{bp}, 500 \mathrm{bp}$ and $450 \mathrm{bp}$. These were useful for testing of food products containing wheat. In addition, our results showed that the K500 set was superior to the K800 set.
\end{abstract}

(Received Jun. 26, 2006 ; Accepted Oct. 26, 2006)

Keywords : Wheat, Detection, Primer, PCR

キーワード: 小麦, 検出, プライマー, PCR

食品の安全性に関して国はいくつかの法律を定めている が, そのうち食品衛生法は 2001 年に改正され, アレルギー 物質を含む食品として小麦，そば，卵，乳，落花生の 5 品 目を義務表示, 20 品目を推奨表示する旨が記載されている (http : //www.hourei.mhlw.go.jp/hourei/).この中で 小麦は主食となる主要穀物の 1 種であり, 平成 15 年度の 国内流通は約 650 万トンと 5 品目の中で最む多く, この量 から考えても表示に対する正確性は重要と考える。この検 出に関し，公定法ではまず，ELISA 法で確認し，陽性の場 合にはさらに PCR 法で確認することが明記されている.

近年, PCR 法による食品の材料判別法が数多く報告さ れている(1) 8). しかし, 食品の種類や加熱履歴により DNA の状態が異なり ${ }^{9)}$, その結果偽陰性を出す可能性が考えら れる. 一方, 公定法による小麦の PCR 検出では 1 プライ マーセットのみ記載され擬陽性, 偽陰性が懸念される。さ

7156-8502 東京都世田谷区桜丘 1-1-1

* $=156$-8502 東京都世田谷区桜丘 1-1-1

$\S$ 連絡先 (Corresponding author), muchino@nodai.ac.jp
らに，結果への信頼性向上を考慮すると複数のプライマー セットを用意することが望ましいと考える，そこで，本研 究では新たな小麦検出用プライマーセットを開発すること を目的とした。

\section{実 験 方 法}

\section{1. 実験材料}

小麦試料として代表的な国内麦の 1 つであるホクシンを 用いた。 また，対照として近縁で小麦アレルゲンを含有する ライ小麦の他, うるち米 (コシヒカリ), 雑穀類（大麦, ア ワ, キビ, 栽培ヒエ, モロコシ, ライ麦), 系統的に離れた微 生物 (Aspergillus kawachii, Saccharomyces cerevisiae, Saccharomyces pombe), マウス血液および大豆を用いた.

\section{DNA 抽出および PCR 増幅性の確認}

DNA 抽出および精製は Gen Elute Plant Genomic DNA Kit（シグマ社）を用いた。ただし，マウス血液はフェノー ル・SDS 法 ${ }^{10)}$, 微生物 3 種は, ISOPLANT（日本ジーン 社）を用いて行った。 DNA 量および精製度の確認は紫外 
部における吸光度より求め ${ }^{11)}$, 精製度 O.D. $260 \mathrm{~nm} /$ O.D. $280 \mathrm{~nm}$ が 1.5 を超えた DNA を以後の試験に用いた。な お，すべての DNA に対する PCR 増幅性は $18 \mathrm{~S}$ rDNA 領 域の増幅より確認した ${ }^{12)}$.

\section{3. 小麦特定用プライマーを利用した小麦特異的バンド の検出}

小麦特定用プライマーの検索のため, 著者らの研究室で 作成した穀類, 微生物の特定遺伝子領域を増幅するプライ マーセット，約 20 種（フォワードとリバース計 40 プライ マー）を組み合わせて検討を行った（結果省略）。その結果， 以下の 2 種類の組合せが有効と思われた。すなわち，小麦 1 （フォワード : UNI2f, 5' - TGAACSTCGTGTTCGTC - 3', リバース : VIEr, 5' - AGCTTCATGTAGGCGA - 3') およ び小麦 2（フォワード：WHEf, 5'-AGTTCCGAAGAGATCAGACAA-3'，リバース：GBSSf, 5'-ATCACATGGCAAGCATCACA-3')。なお，UNI2f, GBSSf はそれぞれ， 穀類, 小麦のデンプン合成遺伝子を増幅するためのユニ バーサルフォワードプライマー, WHEf は小麦の同遺伝子 を増幅するためのフォワードプライマー, VIEr は Bacillus vietnemensis 特定用リバースプライマーとして構築さ れたものである。小麦の反応液は鋳型 DNA (100 ng/ $/ \mu 1) 1$ $\mu 1,10 \times \mathrm{PCR}$ 緩衝液 $5 \mu 1,2.5 \mathrm{~m} M \mathrm{dNTP}$ 混合液 $4 \mu 1,7^{\circ}$ ラ イマー $(20 \mathrm{p} M / \mu 1)$ 各 $0.5 \mu 1, \mathrm{Ex}$ Taq DNA ポリメラーゼ （5U/ $\mu 1$, タカラバイオ社） $0.2 \mu 1$, 超純水 $38.8 \mu 1$ の計 $50 \mu 1$ とした. PCR 反応条件は初期变性を $94^{\circ} \mathrm{C} ， 5$ 分行い，变性 $94^{\circ} \mathrm{C}, 0.5$ 分, 会合 $51^{\circ} \mathrm{C}, 1.0$ 分, 伸長 $72^{\circ} \mathrm{C}, 1.5$ 分を 30 サ イクル後, $72^{\circ} \mathrm{C}, 7$ 分で最終伸長反応を行った。 なお, PCR 装置は Genamp 9700 (アプライドバイオシステム社)を使 用した。 PCR 後の増幅産物の確認はアガロースゲル電気 泳動にて行った。染色はエチジウムブロマイドで行い，紫 外線照射にてバンドを確認した。分子量の推定は市販の分 子量マーカーを利用し, ゲルプロアナライザー（プラネト ロン社）にて解析した。

4. 小麦特異的バンドのクローニングおよび塩基配列の 決定

小麦 2 セットで PCR 反応後確認された小麦特異的バン ドを紫外線照射下で切り出し, LaboPass Gel (北海道シス テムサイエンス社）にて増幅産物の回収执よび精製を行っ た。精製後の増幅産物を pGEM-T Easy Vector System 1 (プロメガ社)を用いてプラスミドにライゲーションし，E. coli JM 109 株に Micropulser（バイオラッド社）を使用 し，エレクトロポレーション法にて遺伝子導入を行った。 形質転換した大腸菌を培養し，新鮮菌体からアルカリー SDS 法 ${ }^{11)}$ にてプラスミドの抽出を行った。抽出プラスミ ド上の目的遺伝子のシークェンス反応は M13 プライマー および Big Dye ver. 3.1 を使用して Geneamp 9700 （アプ ライドバイオシステムズ社）にて行った。 反応後の増幅産 物を精製後, DNA オートシークエンサー（ABI 3100 Avant,
アプライドバイオシステムズ社）にかけ，DNA 塩基配列 を決定した。決定した塩基配列の相同性検索は BLAST お よびFASTA（DDBJ : http : //www.ddbj.nig.ac.jp/) ${ }^{12}$ を利用した。

\section{STS プライマーの設計と特異的 PCR 増幅性の確認}

決定した塩基配列之相同性検索でスコアの高い配列情報 をClustal W を用いてアライメントし ${ }^{14)}$ ，特異配列性，GC 含量や DNA 長を考慮して STS プライマーを設計した。設 計したプライマーおよび STS 化の基になったプライマー の組み合わせにより，小麦特定のための試験を行った。な お，PCR 条件を検討した結果，K800 ではアニーリング温 度が $50^{\circ} \mathrm{C}, \mathrm{K} 500$ では $55^{\circ} \mathrm{C}$ の反応条件が適しており，前述 の PCR 条件のアニーリング温度のみ変えて試験した。

\section{6. 構築したプライマーを用いた小麦含有食品での PCR 増幅性}

実験試料として食パン (内層を使用), 茹でうどん, 茹で ラーメン，そうめん（乾物）および小麦粉を用いた。試料を 乳鉢で擂り潰した後, DNA をGen Elute Plant Genomic DNA Kit（シグマ社）で抽出・精製した。プライマーは 5 で構築したプライマーセットを利用した。また，PCR 反応 液組成や反応条件, 電気泳動での増幅産物の確認は前述之 同じ条件で行った。

\section{実験結果および考察}

\section{1. 小麦特定バンドの検出}

小麦 1 セットプライマーで試料の DNA を PCR 増幅し, 電気泳動した結果を Fig. 1 に示した. 小麦，ライ小麦㧍よ びライ麦にて $410 \mathrm{bp}$ ，モロコシおよびA. kawachii にてそ れぞれ $700 \mathrm{bp}$ 抢よび $500 \mathrm{bp}$ のバンドを確認した。 また， 小麦 2 セットプライマーで試験した結果を Fig. 2 に示し た. 小麦, 米, 大麦, アワ, 栽培七エ, モロコシ, ライ麦, および A. kawachii で数本のバンドが確認された。 小麦之 ライ小麦では他の試料とは異なる 800 bp および 500 bp の バンドを確認した.

小麦のアレルギー物質は小麦だけでなく小麦とライ麦を 交雑してつくられたライ小麦にも含まれている。このこと から小麦およびライ小麦に特徵的なバンドの検索が重要で ある．小麦 1 セットでは他の試料には見られない小麦なら びにライ小麦に特徴的なバンドが確認されているが，ライ 麦む同分子領域に確認できるため，この段階では小麦とラ イ小麦の特定が困難である。しかし，小麦 2 セットでは小 麦およびライ小麦に特徵的なバンドが 2 本確認できるた め,これらの 2 試料の特定には小麦 2 セットが望ましいと 考える。なお，今回用いた小麦 1 セットおよび 2 セットを 組み合わせることによりライ麦の特定む可能となった。

\section{2. 小麦 2 セットによる増幅産物の塩基配列とプライ} マーの設計

PCR 結果から小麦の推定を容易にするには，PCR 後に小 


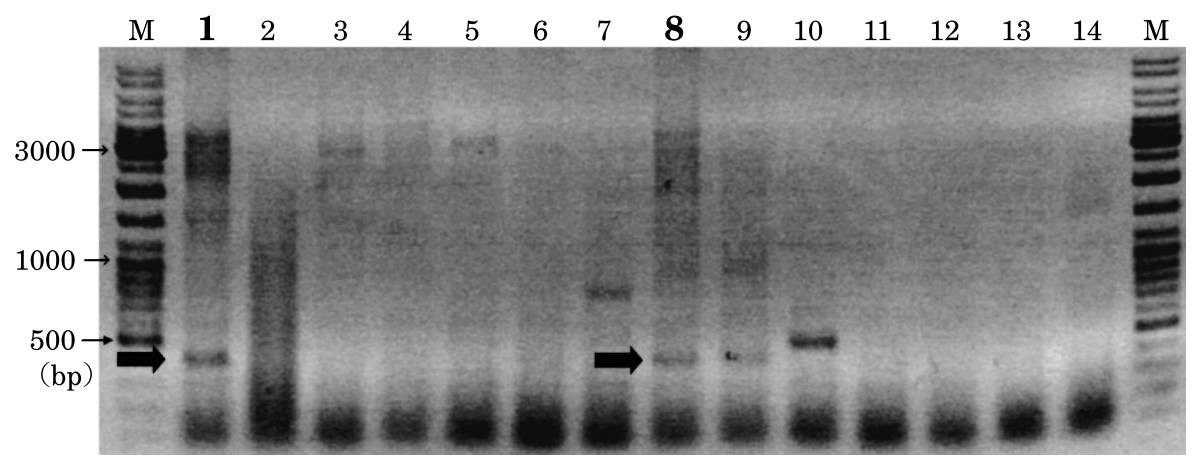

Fig. 1 Electrophoresis of amplified DNA using WHEf-GBSSf primer set

Abbreviations: 1, Wheat;2, Non-glutinous rice; 3, Barley; 4, Foxtail millet; 5, Proso millet; , Japanese barnyard millet; 7, Sorghum ; 8, Rye-wheat ; 9, Rye ; 10, A. kawachii ; 11, S. cerevisiae ; 12, S. pombe ; 13, Rat ; 14, Soybean ; M, Molecular weight marker.

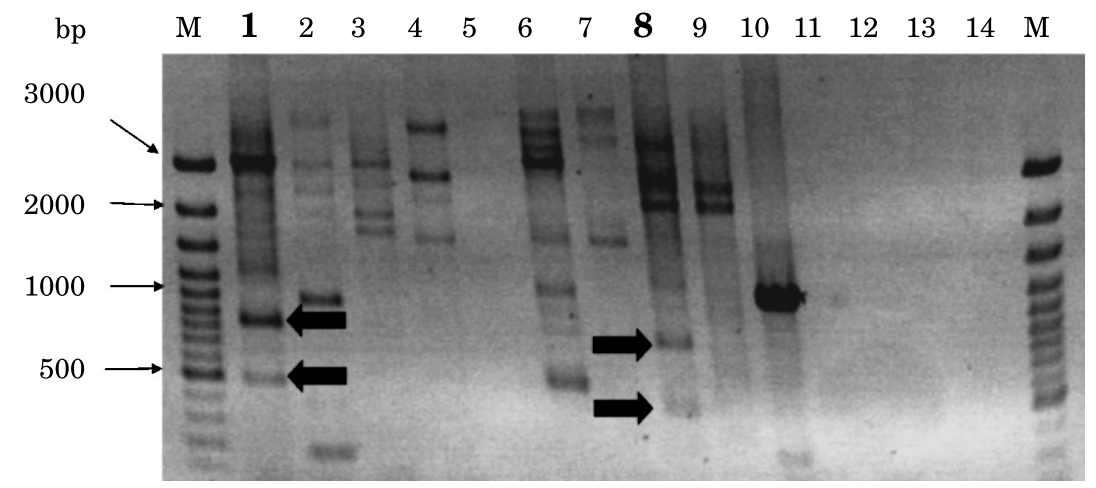

Fig. 2 Electrophoresis of amplified DNA using UNI2f- VIEr primer set

Abbreviations : 1, Wheat;2, Non-glutinous rice; 3, Barley; 4, Foxtail millet; 5, Proso millet; 6, Japanese barnyard millet ; 7, Sorghum ; 8, Rye-wheat ; 9, Rye ; 10, A. kawachii ; 11, S. cerevisiae ; 12, S. pombe ; 13, Rat ; 14, Soybean ; M, Molecular weight marker.

麦およびライ小麦のみ増幅バンドが確認されるのが望まし い. 前述の結果を考慮すると, 小麦 2 セットで増幅した小麦 特定バンドから特定プライマーについて検討した。 小麦 2 セットで確認された $800 \mathrm{bp}$ および $500 \mathrm{bp}$ の各バンド（以下 K800，K500 とする）の塩基配列を決定した（Table 1).な お，決定した塩基配列を相同性検索した結果（FASTA およ び BLAST, DNA query vs. DNA database), K800, K500 と あに高い相同性を示すむのはヒットしなかった（10\%以下）. そこで，GC 含量などを考慮し，新たな STS プライマーを構 築した。なお， $800 \mathrm{bp}$ を基にしたものは塩基配列の $5^{\prime}$ 末端側 が他の登録配列と類似性が高かったため, 小麦セット 2 フォ ワードを利用し， 3’末端側のみ作成した。作成したプライ マーはK800r (5'-CGTGACAGAAGGTGATGAGGCT-3’） である。また， $500 \mathrm{bp}$ を基にしたものはフォワードが $\mathrm{K}$ 500f (5'-TCGTGTTCGTCATCATCGTC-3') でリバース がK500r（5'-CTTCATGTAGGCGAAACCGA-3') であ る.これらのプライマーを利用して各 DNA をPCR 増幅 した結果を Fig. 3 に示した. なお，K800のフォワードは

\section{K800 (UNI2f-K800r primer)}

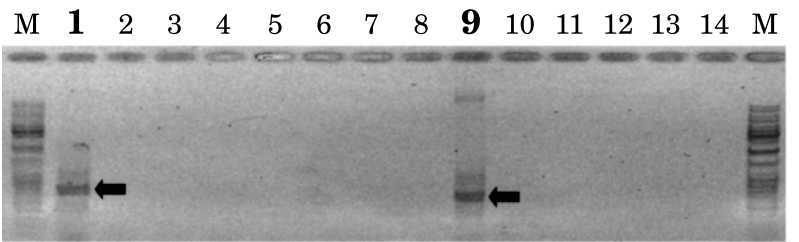

\section{K500 (K500f-K500r primer)}

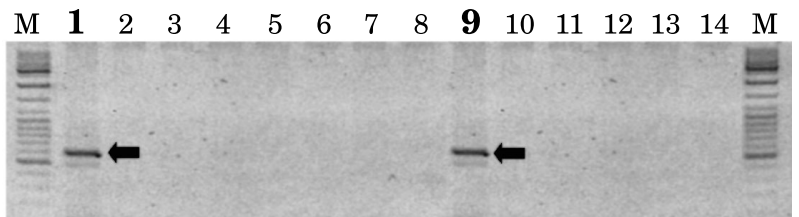

Fig. 3 Wheat-specific bands amplified with STS primer Abbreviations : 1, Wheat ; 2, Non-glutinous rice ; 3, Barley ; 4, Foxtail millet; 5, Proso millet; 6, Japanese barnyard millet; 7, Sorghum ; 8, Rye ; 9, Rye-wheat 10, $A$. kawachii ; 11, S. cerevisiae; 12 , S. pombe ; 13, Rat; 14, Soybean; M, Molecular weight marker. 
Table 1 Sequences of two wheat-specific bands amplified with UNI2f-VIEr primer sets

GGGCTATCGTCTTGGTGCCTAGCAAGAAGTGTCTGGAATACTCATGGCA CACGATTAGTCTCGCAAATGCGTTGTCATCAATCACCAAAACACTTAGG GATAAATATGTCCTTACAATCTCCCCCTTTTTGGTGGATTGATGACAAAG CGGGATTTGCACAAGGAAAATATACTATTAAGTAAAAGGCAAACCCCTC CCTCTCTATAATATAGATGGGCTCCCCCTAAATGTGTGCCACCTAGATG AGCACGAATACTAGGAACAGAGCTCCCCCTATATTATATAGACAAGGCA AATTTATCACTAGACAAGATAGTACAGACATAAGATAACTAAGATAGAT AGAGTGCATATGTCTTACACCATATGGAGGATAGGTCTCGAAGGCACAA ACCGAACAAAAGCAAACGAGGCAAACAAGGTTCAAACGACAAAGCAA ACAAACACACCAAGCACGACACAACGCAAATCCCTACACTCTCTCCCC CTTTGGCATCGAGACGCCAAAAAGGCAGAGAGGACACCCTACACACAC GGGGTGGCTCAGGCAGAGAAGTCGTCCCACTGCTCCTCGTGCTCCTCG TCAGACTCAGCAGGCGGGGATAGTCTCCTCAATGTCATCCTCTGAACTG GTCCACTTGTAGCCCTGCTTTGACATCCAGGCAGCnTaCAGGTGTGATG ACGTCCTCAGACCCGCCAGACACATCCGATCCAAAGAGCCTCATCACC TTCTGTCACGGCGGAGACTCTCCTGTCAGTCAC

Sequences of amplified product located at $800 \mathrm{bp}$.
TTGAACGTCGTGTTCGTCATCATCGTCATGGTAGTTGTGCCTGGG TTATGTTGTAGCCGACCGTGCTCAGGCTCTCACGGTGGATGGTT CTTGCTTTCATGCATTGTGCTTCACTTTTGTTCTAATCTAGGATGG GTTGGATCTTCTTATAGTTTTGGATCGATGATTCAAGAGAGTCGA TGTGCAACTCTCCTACATATGGTTAGGAAAAAACTATGAACACTA GGGGCAGGGTGTCAAACTAGTGGGGAAGCTTTTCTAGTCAACTG CCCCCACGTCGCTGCCTAGGCGACTCAGGCGGCCACCCATCCT CGTCGCCGGAGGGTGGTCCTCACTTCCCTCCCCTCATCGTCATT GTCGATTGACGCCACCGGGGATCTGCCCTAGAGGACGATGGTG GTGGCGAGCCATCTTCCTCTCGTCCTACATGCTCCGACATCCTTT CTGA TGAGGCCTCCC TA TCGGT T TCGCCTACA TGAAGCT A

Sequences of amplified product located at $500 \mathrm{bp}$.
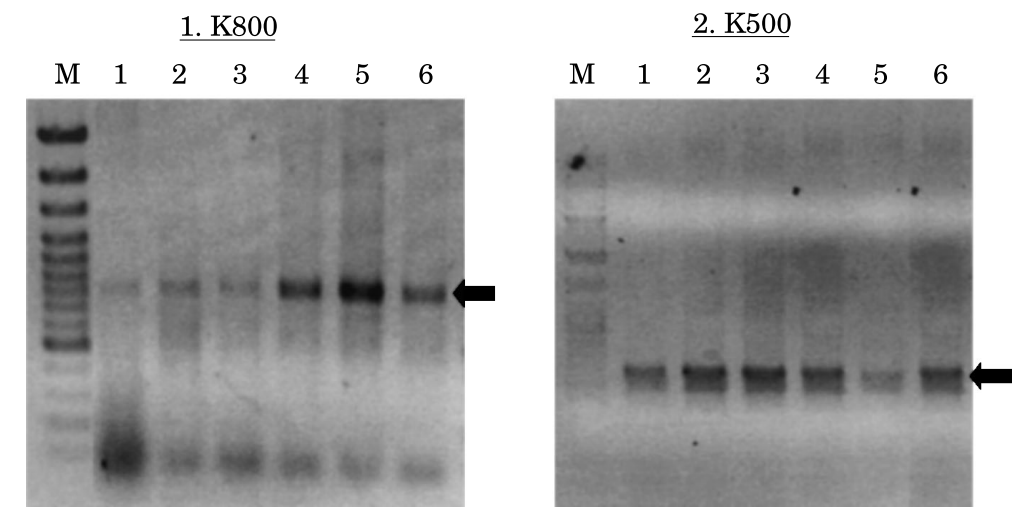

Fig. 4 Application of wheat-specific STS primer to commercial food products

Abbreviations: 1, Bread;2, Noodle; 3, Chinese noodle; 4, Soumen; 5, Strong flour;6, Cake flour, M ; Molecular weight marker.

UNI2f を使用した。 K800 については小麦とライ小麦にの み $800 \mathrm{bp}$ の増幅産物を確認した。また，同様に K500につ いても小麦とライ小麦のみにバンドが見られたものの, 500 bp の主バンドの他に $450 \mathrm{bp}$ 付近にうすいバンドが確認さ れた。なお，結果には示していないが，理論上食品中に小麦 が $0.01 \%$ 以上含まれていれば検出ができることを確認して いる.

以上より，構築したプライマーセットの利用により PCR にて小麦およびライ小麦を特定できることが明らか となった。

\section{3. 食品への適用}

K800 および K500 のプライマーセットを小麦含有食品 に適用した結果を Fig. 4 に示した，K800 については増幅 バンドに差が見られるものの，すべての試料で $800 \mathrm{bp} に$ 確認された。 また，K500についても強力粉で若干バンド が薄いものの, すべての試料で濃いバンドが 500 bp に, 薄 いバンドが 450 bp に確認された．K800 および K500 の電 気泳動写真を比較すると K500 の方が試料間で均一で明確
であるため，食品中の小麦の検出には K500 が適している と考える。

PCR は一部食品の材料特定の方法として，その簡便性や 迅速性が優れているものの，DNA の精製度や量が不十分 なために偽陰性を示す場合がある。そのため，今回のプラ イマーセットだけでなく，他のプライマーも併用して PCR 増幅性を確認した方が良いと考える，我々は PCR 増幅性 の確認のために真核生物のすべてが持ち，原核生物は持た ない 18S rDNA 領域の PCR 増幅性をその目安に適してい るとの報告をした ${ }^{15)}$ 。このことから K500 と $18 \mathrm{~S} \mathrm{rDNA}$ 領 域の両方の増幅性で小麦が食品に含まれるかを判断するの が望ましいと考える，また，食品の多くはその加工過程で 加熱をするが，我々の実験から DNA 自身を加熱すると $120^{\circ} \mathrm{C}$ から $130^{\circ} \mathrm{C}$ で分解が起こり PCR 増幅できないが，食 品の中心から抽出した DNA はクッキーのような加熱条件 の㛜しいものからであ PCR 増幅することが分かった。そ のため, 実際に食品を検査する場合には熱履歴を考慮し, 温度ができるだけかからない部分の使用が望まれる。 
要 約

食品衛生法で表示義務を定められている小麦について, PCR 法における新しいプライマーセットの開発を行った. その結果，UNI2f と VIEr プライマーの組合せで， 約 800 $\mathrm{bp}$ と $500 \mathrm{bp}$ に小麦および小麦アレルゲンを含有するライ 小麦に特徴的なバンドを示した。 特徴バンド以外にもバン ドが存在するため, 検出時の判定の簡便化のために両バン ドをクローニング，シークエンスを行った．決定した配列 を基に STS プライマーを設計した。構築したプライマー のうち, K500 は加工食品由来 DNA で試験した際にバン ドが明瞭であった。 以上, 本研究では新しい小麦検出用プ ライマーセットK500を開発した。

\section{文献}

1) Quinteiro, J., Sotelo, C.G., Rehbein, H., Pryde, S.E., Medina, I., Perez-Martin, R.I., Rey-Mendez, M. and Mackie, I.M., Use of mtDNA direct polymerase chain reaction (PCR) sequencing and PCR-restriction fragment length polymorphism methodologies in species identification of canned tuna. J. Agric. Food. Chem., 46, 1662-1669 (1998).

2) Martinez, I. and Danielsdottir, A. K., Identification of marine mammal species in food products., J. Sci. Food Agric, 80, 527-533 (2000).

3) Mihalov, J.J., Marderosian, A.D. and Pierce, J.C., DNA identification of commercial ginseng sample. J. Agric. Food. Chem., 48, 3744-3752 (2000).

4) Miguel, A.P. and Begona, P.-V., Identi · cation of commercial canned tuna species by restriction site analysis of mitochondrial DNA products obtained by nested primer PCR. Food Chem., 86, 143-150 (2004).

5）中村澄子, 鈴木啓太郎，原口和朋，与座宏一，奥西智哉，大 坪研一, 松井崇晃, 石崎和彦, 吉井洋一, 屯ち加工品におけ るもち米の品種判別および異種穀類の混入検出技術の開
発, 農化, 78, 984-993 (2004).

6) Saez, R., Sanz, Y. and Toldra, F., PCR-based fingerprinting techniques for rapid detection of animal species in meat products. Meat Science, 66, 659-665 (2004).

7) Maria, L.-A., Laura, L., Amando, G.-P., M. Isabel P. and Antonio, $\mathrm{P}$, Identification and quantitation of species in complex DNA mixtures by real-time polymerase chain reaction. Anal. Biochem., 339, 73-82 (2005).

8）内野昌孝, 山岸 亨, 辻井良政, 高野克己 RAPD 法によ るもち精米の品種判別について。 日食保蔵誌，29，47-50 (2003).

9) Uchino, M., Noguchi, T. and Takano, K., Thermostability of DNA from wheat in heated food products. Food Pres. Sci., 30, 195-198 (2004).

10) Saito, H. and Miura, K., Preparation of transforming deoxyribonucleic acid by phenol treatment. Biochem. Biophy. Acta, 72, 619-629 (1963).

11) Watson, J.C. and Thompson, W.F., Purification and restriction endonuclease analysis of plant nuclear DNA. In "Methods for Plant Molecular Biology." eds. Weissbach, A. and Weissback, H., Academic Press, Inc, pp. 57-76 (1988).

12) Okada, G., Takematsu, A. and Takamura, Y., Phylogenetic relationships of the hyphomycete genera Chaetopsia and Kinochaeta based on 18S rDNA sequences. Mycoscience, 38, 409-420 (1997).

13) Tateno, Y., Saitou, N., Okubo, K., Sugawara, H. and Gojobori, T., DDBJ in collaboration with masssequencing teams on annotation. Nucleic Acids. Res., 33, D25-D28 (2005).

14) Thompson, J.D., Higgins, D.G. and Gibson, T.J., CLUSTAL $\mathrm{W}$ : improving the sensitivity of progressive multiple sequence alignment through sequence weighting, position-specific gap penalties and weight matrix choice. Nucleic Acids Res, 22, 4673-4680 (1994).

15）内野昌孝, 野口智弘, 高野克己. 抽出 DNA の PCR（Polymerized Chain Reaction) 増幅性の確認. 日食保蔵誌，29, 335-338 (2003).

(平成 18 年 6 月 26 日受付，平成 18 年 10 月 26 日受理) 